\title{
Implementation of Problem Based Learning to Improve the Critical and Creative Thinking Skills
}

\author{
Asmiatin Anisaroh, M.V. Roesminingsih, Totok Suyanto \\ Universitas Negeri Surabaya \\ Surabaya, Indonesia \\ asmiatin.anisaroh@gmail.com
}

\begin{abstract}
This is a class action research that aims to improve students' critical and creative thinking skills through the application of problem-based learning model on fourth-grade students of SDN Gayungan I / 422 Surabaya. This study was conducted during two learning cycles. The subjects of the study were the fourth-grade students of SDN Gayungan I/422 Surabaya in the second semester of the academic year 2017/2018. Data collection techniques used in the research are observation and test. Data analysis used is quantitative descriptive analysis. The finding indicates that the use of problem-based learning model can improve critical thinking and creative skills of fourth grades in social studies lesson. The results of this research include (1) students' critical thinking skill by $71 \%$ in cycle $I, 83 \%$ in cycle II; (2) students' creative thinking skill by $71 \%$ in cycle $I, 83 \%$ in cycle II. Based on the results of the study can be concluded that the application of problem-based learning model can improve students' critical and creative thinking skills in social studies subject of the fourth grade of SDN Gayungan I/422 Surabaya.
\end{abstract}

Keywords-Problem Based Learning; Critical and CreativeThinking Skill

\section{INTRODUCTION}

Education is the most important means in realizing the progress of the nation and state. Quality of education will create quality human resources. Education can be performed in the family environment, formal education (school) and community. Education at the Elementary School level is the initial level of students to develop basic knowledge to a higher level. In elementary-level education, social studies must be learned by the students. In the curriculum of 2013 social studies do not stand alone as subjects yet integrated into one approach. The content is also only integrated for the higher class of primary 4 to 6 . In the lessons, learning materials are linked to life around students so that students are able to relate the theories they learn by applying in the life around them. One example of the learning materials are economic activities on the theme of my area of residence in class 4 which was taught by using the lecture method. Meanwhile, this material is related to everyday problems that teach students to think critically and creatively to solve problems and provide solutions to the problems contained in the real life of students.

Critical thinking skills are important for students, as they can be used in making decisions and solving problems. Critical thinking is highly necessary for students as it can help students to improve understanding of the material being studied. Students' critical thinking skills need to be developed. Stated that through the process of learning, critical thinking skill can be developed [1].

Critical thinking is thinking that is fair and reflective, focused on deciding what to believe or do [2]. One way that can be developed in training critical thinking skills is finding problems, analyzing, and determining alternative solutions to the problem-solving. Creative thinking is a high-level thinking is needed to solve problems that are or will be faced in the daily life of students.

Stated that creative thinking is a process that to solve problems encountered by thinking sensitive to existing problems, defining difficulties, finding solutions, guessing, creating alternative solutions and testing them, refining and communicating the results [3]. When a person is faced with a problem, then one will think about how to find a solution to the problem. A person's skills, when faced with such problems, can be regarded as creative thinking skills.

Based on the results of observations of researchers during the learning process of Social Studies on the subject of economic activity, learning activities and critical thinking skills and creative students in grade IV SDN Gayungan I / 422 Surabaya is still low. This is indicated by students not daring to argue, ask questions, merely listen to the teacher and do not give the idea to solve the problem because the students prefer to memorize the material.

From the document of critical thinking test result of grade 4 students showed that from 24 students who scored 75 100 were 7 students (29\%), 50-74 were 13 students (54\%), and the score of $0-49$ were 4 students $(17 \%)$. That means only 7 students $(29 \%)$ score above the minimum criteria, while the remaining $17(71 \%)$ students still score below the established of 75 (according to school).

The results of interviews with students show that the students do not understand the material that has been studied when given the question of the material they just learned by replying with the short answer and according to the book. When told to read in a book, students merely read the rest at a glance used to chat with friends. Knowledge delivered by the teacher was not well absorbed by the students so that students 
found difficult to solve the problems set forth in the matter. When teachers gave oral questions about samples of production, distribution, and consumption around students, only six students actively answered questions while others were passive.

When students were asked the question of how humans meet their living needs, local people's work, and activities of production, distribution, and consumption, students simply memorized the notion of production, distribution, consumption but they could not explain from the possible problems encountered at the time of production, distribution, and consumption. Students were able to explain the constraints faced in economic activity. This indicates if students have not been able to find alternative solutions and have not had critical and creative thinking skills.

Critical and creative thinking skills of fourth-grade students of SDN Gayungan I / 422 Surabaya were still low, students' activity in the class were passive. The role of teachers is very important in teaching and learning activities in the classroom. In practice, teachers should use strategies and teaching models that involve active students and are able to think critically and creatively in solving problems in classroom learning.

Based on these problems, a solution to improve learning activities needs to be undertaken. Teachers should provide opportunities for students to be more active in the learning process and able to think critically and creatively. One effort to improve students' critical and creative thinking skills in social studies is to use problem-based learning model. States that in applying the problem-based learning model, students work on authentic issues encompassed around the student's environment in order to develop their own knowledge, develop inquiry and high-level thinking skills, and develop self-reliance and self-confidence [4].

Problem-based learning facilitates successful solving problems, communication, group work, and individual skills compared to other learning models. The problem-based learning model is a learning that starts from the environment around students as learning materials of social studies.

Problem-based learning is a model of learning that is designed and developed to develop students' ability to solve authentic problems that exist in the environment around students [5]. The opinion assumes that problem-based learning focuses on the authentic problems presented by the teacher, while the students are expected to be able to solve a problem with the knowledge and skills that students have from the learning resources that can be obtained. Problems given in learning are authentic problems, not artificial problems so that students better understand in the process of problem-solving. That authentic issues can attract students' interest because they are related to the daily life of the students and beneficial to themselves [6].

Problem-based learning encourages students to make connections between the knowledge they already have and the student's daily life. Learning process using problem-based learning can familiarize students face and solve problems skillfully and improve students' critical and creative thinking ability. Problem-based learning is a learning model in which students work on authentic issues with the intent to structure their own knowledge, develop inquiry and higher-order thinking, develop independence, and self-confidence [7]. Learning by the model based on the problem makes a real problem at the beginning of student learning process. Students critically identify relevant information and strategies and conduct investigations to resolve the issue. By solving the problem students gain certain knowledge while developing critical and creative thinking skills in solving problems. Students are expected to solve the problem of economic activity in the environment around the students so that the student activity becomes active in teaching and learning activities, as well as students' critical and creative thinking ability, can also increase. So that students not only sit in the classroom but also can interact with the surrounding environment to solve the problems encountered.

\section{RESEARCH METHOD}

This study uses a classroom action research design. Kemmis and Mc Taggart model is used with a sustainable, repeatable cycle (cycle spiral), i.e. increasing the learning process for achieving results. The research was conducted in four steps: (1) planning; (2) implementation; (3) observation; (4) reflection [8].

Independent variable is a study based on problem and the dependent variable is critical and creative thinking skill. The subjects in this study are the fourth graders of 24 students consisting of 9 male students and 15 female students.

Data collection technique uses critical thinking skills tests and tests of creative thinking skills. This test is in the form of written test questions that require critical and creative thinking skills provided in each cycle.

Data are analyzed by quantitative descriptive technique. Critical thinking skills and creative thinking skills are analyzed by using the formula as follow:

$$
\text { Final Score }=\frac{\text { totally score } \text { which is obtained }}{\text { maximum totally score }} \times 100 \%
$$

Indicators of research success are (1) individual critical thinking skill reaching minimum criteria $\geq 75$. While classical completeness is achieved when reaching a minimum of $80 \%$ of all students in the class; (2) The result of the students' creative thinking skill test individually reaches minimum criteria $\geq 75$. While classical completeness is achieved when it reaches a minimum of $80 \%$ of all students in the class.

\section{RESULT AND DISCUSSION}

The initial stage of this research is planning i.e composing learning device and research instrument. Learning tools arranged is the implementation of learning plan, students' worksheets, and teaching materials. The research instrument 
is a test sheet of critical thinking skills and a test sheet of creative thinking skills. Prior to use in learning, learning tools, and research instruments are validated in advance to test their validity by two competent experts in their field.

The second stage in this research is action/implementation. This research was conducted in two cycles and each stage of action was carried out in five stages according to the learning stage based on the problem. The five stages are student orientation on issues, organize students to learn, guide independent and group investigations, develop and present the work, analyze and evaluate the problemsolving process [10].

The third stage is the observation including the results of tests of critical and creative thinking skill in cycles I and II obtained after the students finished working on the end of the cycle.

\section{a. Results of the Critical Thinking Skills Test}

Table 1

Results of Critical Thinking Skills Test

\begin{tabular}{|c|c|c|c|}
\hline \multirow[b]{2}{*}{ No } & \multirow{2}{*}{$\begin{array}{l}\text { Critical Thinking } \\
\text { Indicators }\end{array}$} & \multicolumn{2}{|c|}{ Average mark } \\
\hline & & Cycle I & $\begin{array}{c}\text { Cycle } \\
\text { II }\end{array}$ \\
\hline 1 & $\begin{array}{l}\text { Identify subject matter of } \\
\text { economic activity in the } \\
\text { surrounding environment }\end{array}$ & 81 & 88 \\
\hline 2 & $\begin{array}{l}\text { Suggest reasons for } \\
\text { problems occurring in the } \\
\text { environment based on } \\
\text { logically relevant } \\
\text { evidence }\end{array}$ & 73 & 76 \\
\hline 3 & $\begin{array}{l}\text { Make a logical } \\
\text { conclusion the effect of } \\
\text { diversity of economic } \\
\text { activity as the identity of } \\
\text { the Indonesian nation }\end{array}$ & 76 & 80 \\
\hline 4 & $\begin{array}{l}\text { Decide the solution } \\
\text { logically from the } \\
\text { economic problems that } \\
\text { occur in the environment }\end{array}$ & 76 & 82 \\
\hline 5 & $\begin{array}{l}\text { Make an explanation of } \\
\text { the solution made }\end{array}$ & 56 & 80 \\
\hline & Average & 72 & 81 \\
\hline
\end{tabular}

In the table above, every indicator of critical thinking has increased from cycle I to cycle II. The average of indicator to identify the subject matter in cycle I was 81 and increased to 88 in cycle II. The average of indicator proposing reason of problem in cycle I was 73 and increased to 76 in cycle II. In the indicator of making a logical conclusion on the first cycle was 76 and increased to 80 in cycle II. The indicator of deciding solution logically on cycle I was 76 and increased to 82 in cycle II. The indicator of making an explanation of solution in cycle I was 56 and increased to 80 in cycle II. The increase of on the indicator from cycle I to cycle II cannot be separated from a teacher's role in learning.
The classical completeness in learning that has been implemented has increased in each cycle. Below is the table of classical completion of critical thinking skill.

Table 2

Percentage Completion of Critical Thinking Skills Tests

\begin{tabular}{|c|c|c|c|c|}
\hline No & Criteria & Interval & \multicolumn{2}{|c|}{ Percentage } \\
\cline { 4 - 5 } & & $86-100$ & $16.67 \%$ & $50 \%$ \\
\hline 1 & $\begin{array}{c}\text { Very } \\
\text { Critical }\end{array}$ & & & Cycle II \\
\hline 2 & Critical & $75-85$ & $54.17 \%$ & $33.33 \%$ \\
\hline 3 & $\begin{array}{c}\text { Simply } \\
\text { Critical }\end{array}$ & $60-74$ & $16.8 \%$ & $12.5 \%$ \\
\hline 4 & $\begin{array}{c}\text { Less } \\
\text { Critical }\end{array}$ & $50-59$ & $8.3 \%$ & $4.17 \%$ \\
\hline 5 & $\begin{array}{c}\text { Not } \\
\text { Critical }\end{array}$ & $<49$ & $4.1 \%$ & $0 \%$ \\
\hline \multicolumn{2}{|c|}{$\begin{array}{c}\text { Percentage of Students' } \\
\text { Critical } \geq \text { Critical }\end{array}$} & $71 \%$ & $83 \%$ \\
\hline
\end{tabular}

b. Creative Thinking Skill Test Result

Table 3

Thinking Skills Test Result Data Creative Students

\begin{tabular}{|c|l|c|c|}
\hline No & \multirow{2}{*}{$\begin{array}{c}\text { Indicator of } \\
\text { Creative Thinking }\end{array}$} & \multicolumn{2}{|c|}{ Average value } \\
\cline { 3 - 4 } & Cycle I & $\begin{array}{c}\text { Cycle } \\
\text { II }\end{array}$ \\
\hline 1 & $\begin{array}{l}\text { Fluency, triggering } \\
\text { many ideas }\end{array}$ & 82 & 85 \\
\hline 2 & $\begin{array}{l}\text { Flexibility, resulting } \\
\text { in ideas and answers }\end{array}$ & 72 & 80 \\
\hline 3 & $\begin{array}{l}\text { Originality, resulting } \\
\text { in a new and unique } \\
\text { phrase }\end{array}$ & 78 & 82 \\
\hline 4 & $\begin{array}{l}\text { Elaboration, able to } \\
\text { enrich and develop } \\
\text { an idea or product }\end{array}$ & 63 & 78 \\
\hline \multicolumn{2}{|c|}{ Average } & 74 & 81 \\
\hline
\end{tabular}

From the above data, the average of Fluency in the first cycle is 82 , and an increase in cycle II to 85 . The average of Flexibility in cycle I was 72 and increased in cycle II to 80 . The average Originality indicator in cycle I was 78 and increased to 82 in cycle II. The average Elaboration indicator in cycle I is 63 and increased to 78 in cycle II.

The classical completeness in learning that has been implemented has increased in each cycle. Below is the table of classical improvement of students' creative thinking skill in social studies by using problem based learning.

Table 4

Percentage of Creative Thinking Skills

\begin{tabular}{|c|c|c|c|c|}
\hline No & Criteria & Interval & \multicolumn{2}{|c|}{ Percentage } \\
\cline { 4 - 5 } & & & Cycle I & $\begin{array}{c}\text { Cycle } \\
\text { II }\end{array}$ \\
\hline 1 & $\begin{array}{c}\text { Very } \\
\text { creative }\end{array}$ & $85-100$ & $33.3 \%$ & $50 \%$ \\
\hline 2 & Creative & $75-84$ & $37.5 \%$ & $33.33 \%$ \\
\hline
\end{tabular}




\begin{tabular}{|c|c|c|c|c|}
\hline 3 & $\begin{array}{c}\text { Fairly } \\
\text { Creative }\end{array}$ & $60-74$ & $16.8 \%$ & $12.5 \%$ \\
\hline 4 & $\begin{array}{c}\text { Less } \\
\text { Creative }\end{array}$ & $50-59$ & $8.3 \%$ & $4.2 \%$ \\
\hline 5 & $\begin{array}{c}\text { Not } \\
\text { Creative }\end{array}$ & $<49$ & $4.1 \%$ & $0 \%$ \\
\hline \multicolumn{3}{|c|}{ Percentage of Students $\geq$} & $71 \%$ & $83 \%$ \\
\hline
\end{tabular}

The fourth stage of the study is a reflection. Reflection activity is the stage where the researcher reflects the extent to which the implementation and achievement of learning outcomes based on the application of learning to improve students' critical and creative thinking skills. Findings and observations are discussed together to correct deficiencies and overcome obstacles in the learning process. In the first cycle of the test of critical thinking and creative students' skills have not reached the indicator of the success of the research, it is necessary for the implementation of research in cycle II with some improvement. In the second cycle, there is an increase in the test results of critical and creative thinking skills. This indicates the aspects that became indicators of research success in this action research have reached the target. Every aspect has reached indicator of research success, students' activity aspect and classical completeness of critical thinking skill and creative student reached the percentage of $\geq 80 \%$, the mean value of critical thinking skill and creative student reached $\geq 75$.

Based on these results, the implementation of social studies learning using problem-based learning model can improve critical thinking and creative skills of fourth grade students of SDN Gayungan I/422 Surabaya. Problem-based learning encourages the development of self-learning strategies, improves students' critical thinking and allows students to maintain and apply knowledge to new situations [11].

Problem-Based learning students better understand the learning materials because students themselves find and solve problems encountered so as to provide experience and meaningful for students.

\section{IV.CONCLUSION}

Based on the results of research undertaken by the following concluded.
1. Critical thinking skills in social studies by using problem-based learning on the subject matter of economic activity increased. Students have been working on tests of students' critical thinking skills. It is evidenced by the data value of students' critical thinking skills in learning. The average value of all critical thinking skills indicators in cycle $\mathrm{z}$ I was 72 , while in cycle II reached the value of 81 . Classically the critical thinking skills reached $\geq 71 \%$ in cycle I, increased to $83 \%$ in cycle II.

2. Creative thinking skill by using problem-based learning on the subject of economic activity also increases. In the first cycle, the average score of all the indicators of creative thinking skills is 74 , while in cycle II reached the value of 81 . Classically, the score reached $71 \%$ in cycle I, increased to $83 \%$ in cycle II. This shows that in the second cycle of learning, there is an increase in the students' creative thinking skill test results.

\section{SUGGESTION}

Teachers who want to improve the skills of critical and creative thinking are encouraged to use problem-based learning model for it has been proven to improve critical and creative thinking skills.

\section{REFERENCES}

[1] A. Suprijono, "Model-model pembelajaran emansipatoris," Yogyakarta: Pustaka Pelajar, 2016.

[2] W. Sunaryo Kuswana, "Taksonomi Kognitif Perkembangan Ragam Berpikir.” Bandung: PT Remaja Rosdakarya, 2014.

[3] M. P. Ahmad Susanto, Teori belajar dan pembelajaran di sekolah dasar. Kencana, 2016.

[4] Trianto, Model pembelajaran inovatif berorientasi konstruktivistik, konsep, landasan teoritis-praktis dan implementasinya. Jakarta: Prestasi Pustaka, 2007.

[5] Y. Riyanto, Paradigma baru pembelajaran. Surabaya: Prenada Media Grup, 2012.

[6] I. Suryanti, W. Sukartiningsih, and B. Yulianto, "Model-model pembelajaran Inovatif," Surabaya Univ. Negeri Surabaya, 2008.

[7] R. Arends, Classroom instruction and management. McGraw-Hill Companies, 1997.

[8] A. Suharsimi, Prosedur penelitian suatu pendekatan praktik. Jakarta: Bumi Aksara, 2010.

[9] Jihad, Asep, and A. Haris, Evaluasi pembelajaran. Yogyakarta: Mult Pressindo, 2013.

[10] M. Ibrahim, Pembelajaran berdasarkan masalah. Surabaya: Unesa University Press, 2012.

[11] E. S. Ahlam and H. Gaber, "Impact of problembased learning on student's critical thinking dispositions, knowledge acquisition and retention," J. Educ. Pract., vol. 5, no. 14, pp. 74-83, 2014. 